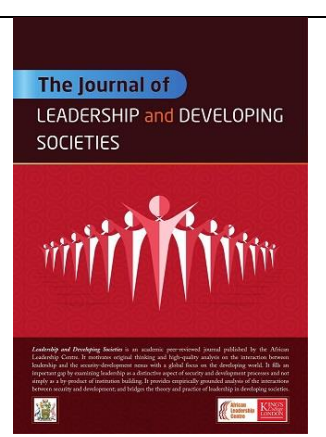

ARTICLE

\title{
Relocating African Agency: Assessing the Role of 'Local Patrons' and Chinese Enterprises in the Construction Sector in Ghana
}

Chris Aldena and Nathaniel Ocquaye ${ }^{b}$

Available online 14 December 2021

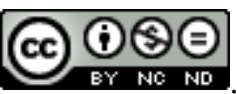

\begin{abstract}
Contrary to the conventional notion that African agency outside of the state is marginal if not irrelevant, this paper argues that it is 'local patrons' in Africa who are actually the most powerful determinants of the success of Chinese enterprises in Africa. These 'local patrons' exact financial resources from the Chinese in exchange for their services as brokers between state officials. Specifically, their 'informal connections' to local state authorities enables them to insure the Chinese firms against official state prosecution/demands as well as facilitate related bureaucratic procedures. Using the case of the Chinese construction firms operating in Ghana, we will investigate the challenges experienced by Chinese firms entering into new markets and the strategies utilised by them to address and mitigate risk in their search for profit, chief amongst them the employment of 'local patrons' to serve as brokers with state officials. This relocation of agency, drawing from scholarship by Mohan, Lampert and Soule-Kohndou as well as the empirical materials based on substantive fieldwork, provides new insights into terms of engagement with local actors that form a bonded relationship facilitating integration of Chinese enterprises into the African political economy.
\end{abstract}

Keywords: China-Africa, African agency, Chinese construction firms, local patrons, middlemen

\section{INTRODUCTION}

The unpacking of the burgeoning relationship between Africa and China has pre-occupied scholarship for the better part of a decade, engaging with the literature on African agency as an avenue to shed insight into these dynamics. Much of the initial focus of research was on

a Chris Alden teaches International Relations at the London School of Economics and Political Science (LSE) and is Director of LSE IDEAS. He is a Research Associate with South African Institute of International Affairs (SAIIA).

b Nathaniel Ocquaye is currently a project support assistant to Professor Chris Alden, Director of LSE IDEAS. negotiations between African governing elites and Chinese counterparts on access to resources in exchange for infrastructure. The findings declared unequivocally that they had 'discovered' agency in the actions of African elites such as the MPLA, Omar Bashir's Sudan or Mugabe's Zimbabwe, for example. ${ }^{1}$

Corresponding author: j.c.alden@lse.ac.uk

1 Corkin, Lucy (2013) Uncovering African Agency: Angola's

Management of China's Credit Lines (Surrey: Ashgate);

Ronald Chipaike and Paul Bishoff (2019) Chinese

Engagement in Zimbabwe and the Limits of Elite Agency, 
This use of African agency is problematic on two counts. The first of these is the 'emancipatory' expression inherent in this misapplication of the concept of agency to the actions of a venal and corrupted political class whose conduct systematically disempowered its citizens. This is typified by Corkin's case of the MPLA whose outreach to Chinese officials in the security sector in 2003 was a response to Western donors and World Bank officials' reluctance to fund post-conflict reconstruction without financial disclosures by the Angolan government. ${ }^{2}$ Moreover, as a recent study of Chinese loan agreements conducted by AidData demonstrates, the presumptions that guide some of the research on agency are misplaced, misunderstood and even over read by scholars eager to find evidence of African subaltern power. In fact, typically these agreements are founded on a combination of non-concessional lending (some deals priced at commercial lending rates) and lock in resources at fixed prices. ${ }^{3}$ The conditionalities imposed in loan agreements are themselves interesting, including non-disclosure of the terms of these agreements and commitments to refrain from incorporating any restructuring discussions with multilateral entities like the Paris Club creditors. ${ }^{4}$

This raises questions as to the positionality of African agency and how this impacts upon our understanding as to the significance of its influence in relations with external powers. However, as work by some Africanist scholars suggests, the positionality of 'agency' is itself significant and resides not only amongst governing elites at the meta-systemic level of analysis but visible in the conduct of African actors at the meso-domestic institutional level and micro-local levels. SouleKohndou's research focuses on the meso-level, examining interaction between Chinese enterprises and African institutional bureaucrats as they negotiate the terms of projects and their implementation. ${ }^{5}$ Procopio's study of Kenya-Africa negotiations foregrounds the complex dynamics of local, regional and national

Journal of Asian and African Studies 54:7, pp.947-964; Mohan, Giles and Lampert, Ben (2013). Negotiating China:

Reinserting African agency into China-Africa relations, African Affairs, 112(446), pp. 92-110.

2 Corkin (2013).

${ }^{3}$ Gelpern, A et al. (2021), How China Lends: A Rare Look into 100 Debt Contracts with Foreign Governments (Peterson Institute for International Economics, Kiel Institute for the World Economy, Center for Global Development, and AidData at William \& Mary)

4 Ibid

5 Soulé-Kohndou, Folashadé, (2020), 'Africa+1' summit diplomacy and the 'new scramble' narrative: Recentering African agency, African Affairs, 119(477), pp. 633-646 interests as well as recognising the role of local business and civil society as sources of influence in that process. ${ }^{6}$ By way of contrast, Mohan and Lampert examine microlevel interactions, where African actors engage with Chinese businessmen as 'middlemen' facilitating commercial activities. ${ }^{7}$

Contrary to the conventional notion that African agency outside of the state is marginal if not irrelevant, our research focuses on the micro-level engagements between Chinese and African actors. This paper argues that it is 'local patrons' in Africa who are actually the most powerful determinants of the success of Chinese enterprises in Africa. These 'local patrons' exact financial resources from the Chinese in exchange for their services as brokers between state officials. Specifically, their 'informal connections' to local state authorities enables them to insure the Chinese firms against official state prosecution/demands as well as facilitate related bureaucratic procedures. Using the case of the Chinese construction firms operating in Ghana, we will investigate the challenges experienced by Chinese firms entering into new markets and the strategies utilised by them to address and mitigate risk in their search for profit, chief amongst them the employment of 'local patrons' to serve as brokers with state officials.

\section{LITERATURE ON LOGISTICS AGENTS, MIDDLEMEN AND CULTURAL BROKER}

The role of middlemen or comparable individuals serving as intermediaries in commercial exchanges is a well-recognised and established area of study from field as diverse as anthropology and business studies. In terms of the study of commerce and the relationship between Africans and Chinese, Mathews describes the role of Africans positioned as intermediaries between African traders and Chinese businesses and officialdom as encompassing logistical agents, middlemen and

6 Procopio, Maddalena (2019), Kenyan agency in KenyaChina relations: Contestation, cooperation and passivity', In Alden, Chris and Daniel Large (eds.) (2019), New directions in Africa-China studies (London: Routledge), pp. 173-188. ${ }^{7}$ Lampert, Ben and Mohan, Giles (2014), Sino-African Encounters in Ghana and Nigeria: From Conflict to Conviviality and Mutual Benefit, Journal of Current Chinese Affairs, 43(1), pp. 9-39; Lampert, Ben and Mohan, Giles (2015), Making Space for African Agency in China-Africa Engagements: Ghanaian and Nigerian Patrons Shaping Chinese Enterprise, in A. W. Gadzala (Ed.), Africa and China: how Africans and their governments are shaping relations with China (Lanham, Maryland: Rowman \& Littlefield) 
'cultural brokers'. 8 His research focuses on the complexities of the transnational wholesale and retail trade between China and Africa. In this regard, he captures the functional dimensions of these agents, middlemen and 'cultural brokers' but sees these as largely unchanging relationships outside of the context in which he describes.

Our research focuses on a different dimension of Africa-China business ties, namely how Chinese private entrepreneurs operating in one sector, construction, in Africa utilise what we call 'local patrons' to facilitate direct business functions and indirect business-related functions in an uncertain environment. We define local patrons in terms of their functional attributes but, in recognition of the changing context and concomitant ongoing learning amongst actors further segment these along temporal lines. Moreover, we contend that this distribution of local patron functions broadly follows the patterns and practices of Chinese businesses domestically and in other regions of the world.

\subsection{The Chinese businesses and overseas economic expansion}

In the South-East Asian communities where the Chinese conduct business, scholars examine how ethnic Chinese establish links with the elite and locals of the various South-East Asian countries in which they operate. ${ }^{9}$ Weidenbaum and Hughes claim that the expansion of Chinese enterprise, or 'bamboo network', is behind the transformation of the regional economy from a backwater to an economic superpower. ${ }^{10}$ At the centre of this process of is xinyong (信用) (trust) and the cultivation of guānxi (关系), sometimes translated as networking, culminating in the ability to mobilise shared ethnicity to the success of Chinese businesses in the region. ${ }^{11}$ Indeed, much of the scholarship points to the combination of personal networks, cultural affinity and Confucian work ethic as sources for its growth and success. ${ }^{12}$ The interplay between these ascribed cultural explanations for business success and state actors is

\footnotetext{
${ }^{8}$ Mathews, Gordon (2015), African Logistics Agents and Middleman as Cultural Brokers in Guangzhou, Journal of Current Chinese Affairs, 4:4, pp.117-144

${ }^{9}$ Gomez, Terence E. (2001), Chinese Business in Southeast Asia: contesting cultural explanations, researching entrepreneurship (Richmond: Curzon Press)

10 Weidenbaum, Murray and Samuel Hughes (1996) The Bamboo Network: How Expatriate Chinese Entrepreneurs are Creating a New Economic Superpower in Asia (New York: Free Press)

11 Koning, Juliette (2007), Chineseness and Chinese

Indonesian Business Practices: a Generational and Discursive Enquiry, East Asia, 24, pp.139-140
}

documented and assessed in countries like Malaysia and Indonesia where historically communities from Fujian and Guangzhou had settled. ${ }^{13}$ Other scholars were sceptical of this exclusively culturalist reading of Chinese business practices, identifying and asserting profit as the fundamental driver of conduct and arbitrator of success. ${ }^{14}$

In Africa, this pattern of Chinese business expansion and its accompanying practices anecdotally seems to be replicated in broad terms. However, this paper recognised that this process was not uniform or linear on the continent, nor was it predicated exclusively on the internal dynamics of Chinese business culture as portrayed in research on Southeast Asia. Rather, it reflects a process in which Chinese entrepreneurs developed knowledge of African business environments and gradually integrated this knowledge into their operational practices in these environments in order to facilitate greater success. In the first instance, it functioned within the changing context of policy environments emanating out of China and within host countries that shaped entrepreneurial trajectories and successes. Finance and contracts acquired through networks derived from within China and in particular through contacts to key state institutions like the policy banks fuelled the first wave of Chinese overseas business expansion into unknown African markets. ${ }^{15}$ When these financial sources were not available or when other larger markets exerted their pull, Chinese SOEs in particular moved on to seek new opportunities. However, one category of Chinese business - that of private entrepreneurs - have employed a different strategy aimed at deepening local networks and integration to generate success.

In this respect the distinction between Chinese SOEs, with their privileged access to Chinese state finance and concurrently exposure to Chinese state regulatory management, and Chinese private entrepreneurs operating largely outside that context becomes an important one to make. Adopting such a distinction echoes some critical research on the gap between

\footnotetext{
12 Kotkin, Joel (1993), Tribes: How Race, Religion and Identity Determine Success in the New Global Economy (New York: Random House); Weidenbaum Hughes (1996); Gomez (2001); Koning (2007)

13 Koning (2007)

14 Gomez (2001)

15 Alden, Chris, and Martyn Davies (2006), A profile of the operations of Chinese multinationals in Africa, South African Journal of International Affairs, 13:1, pp. 83-96; Lam, Katy (2017), Chinese state-owned enterprises in West Africa: Tripleembedded globalization (Routledge)
} 
prevailing scholarship on Chinese conglomerates operating in Indonesia, about which the bulk of the literature is focused, versus small and medium enterprises where the scholarship is much more limited. ${ }^{16}$ For private Chinese companies, the road to success was not exclusively predicated on networks within Chinese state institutions and provincial sources but rather increasingly to be found in fostering greater integration into local networks and more broadly the local political economy. As a result, these private firms engineered a strategic shift away from reliance on intraChinese networks for business opportunities in Africa to one focused on building networks within the local African political economy in order to secure finances, contracts and access markets. This shift amounted to a 'localisation' strategy which relied on Africans as intermediaries to achieve these aims. ${ }^{17}$ This process in turn produced greater opportunities for African agency, mediated through the networks of these intermediaries or middlemen as interlocutors between African governments, local officials, and local communities. In effect, African agency was re-sited and embodied in these middlemen whose networking came to influence the integration process of Chinese private firms into the local political economy.

\section{Chinese Private Construction Companies in Ghana}

In Ghana, as well as many parts of Africa, the state 'is the largest client of the construction industry... Most public construction projects are submitted to national (domestic contractors only) or international (open to foreign firms) competitive tendering'. ${ }^{18}$ It is also a common practice to allow for bidding on various construction projects, as the government aims to find the companies that can deliver at the most affordable price. This is where the Chinese construction companies have a competitive edge: they are both able to deliver in time and with low cost. Over the years, the Chinese construction firms, and the state as well as private clients have developed a strong bond due to the efficiency and cost-saving techniques of Chinese construction firms.

In this article, it is important to make it clear that we are focusing on Chinese entrepreneurs in the

\footnotetext{
16 Koning (2007), pp. 130-131

17 Lam (2017)

18 Auffray, Cyrielle, and Xiaolan Fu (2015), Chinese MNEs and managerial knowledge transfer in Africa: the case of the construction sector in Ghana, Journal of Chinese Economic and Business Studies, 13(4), p. 291

${ }^{19}$ Alves, Ana Cristina (2013), Chinese Economic Statecraft: A Comparative Study of China's Oil-backed Loans in Angola and Brazil, Journal of Current Chinese Affairs, 42:1, pp. 99-130
}

construction sector who have ventured out into Africa from different provinces in China - that is, these are private enterprises (like the ones identified by Lampert and Mohan, 2014). There are Chinese state-owned enterprises (SOEs) in the construction business (e.g., Sinohydro) that have been contracted by the state to undertake various infrastructural projects across Africa sometimes as part of a bilateral deal or an infrastructure for resource loan. ${ }^{19}$ We are referring to the former not the latter. We choose to focus on the provincial construction companies because '(m)any provincial CPEs have developed activities in Ghana, and in Africa in general, far exceeding those carried out by central Chinese state-owned enterprises there'. ${ }^{20}$ Moreover, provincial construction companies from China form the bulk of Chinese construction companies in Ghana, hailing from relatively poor provinces such as Gansu, Shaanxi, Jiangxi. ${ }^{21}$ It is also interesting to note that from China's perspective the provincial companies 'belong' to the provinces even though they are registered as private companies in their various destinations in Africa. Two private companies in particular, Huashan from Shaanxi province and Hualong from Gansu province, have played a dominant role amongst Chinese construction firms in Ghana in the last two decades. Between 1994 and 2014, Huashan secured 50 contracts with $\$ 15$ million of business by combination of multilateral, regional and Ghanaian government sources. ${ }^{22}$ Hualong's record was more checkered, having only moved into profitability after an overhaul of its approach in 2001.23 Hualong's accompanying diversification into construction materials, medicine products, hotels and retail trade through the Hualong Group allowed it to expand annual revenues to a peak of $\$ 100$ million by $2013 .{ }^{24}$

\section{1. "It Takes Two to Succeed": Elites and Local Patrons in Ghana's Construction Sector}

As outlined in the previous section, any examination of the China-Africa relationship within the construction sector reveals two levels of African agency. At the first level are the elites in government and politics. This elite group are very important to the Chinese construction companies for two main reasons. First, in Ghana, as well

${ }^{20}$ Lam, Katy and Bach, Jean-Nicholas (2014), L'INÉVITABLE «LOCALISATION»: LES ENTREPRISES PUBLIQUES CHINOISES DE LA CONSTRUCTION AU GHANA: China, Ltd. Un business africain, Politique africaine, 134, p.30

${ }^{21}$ Lam and Back (2014)

22 Lam (2017), p.57

23 Ibid

${ }^{24}$ Lam (2017), p.67 
as many parts of Africa, the government/state is the main client for the construction industry, thus having connections with the elite in government increases one's chance of getting contracts for various infrastructural projects. Second, these elites have power in the country and as such can facilitate bureaucratic procedures for establishing and obtaining the necessary documents to operate as a construction company. Thus, the Chinese often rely on these elites to quickly get their construction companies established when they arrive in the country.

At the second level are the local patrons. These local patrons may be people akin to the elites, or ordinary people who rally during elections for the elites or they may be close to the traditional leadership (chiefs, for example) or just the indigenes in the community. Between the elites and local patrons, we argue that the local patrons are the most important factor that determines the survival and success of the Chinese construction companies. As noted above, this assertion is even true in the South-East Asian communities where the Chinese do their business. Gomez notes how ethnic Chinese establish links with the elite and locals of the various South-East Asian countries in which they operate. $^{25}$ This demonstrates the importance of networks (guānxi 关系) to the success of Chinese businesses in the region. In the same vein, Chinese enterprises in Africa tend to forge networks when they arrive on the continent, with the key understanding that it is the local networks created that improve the success and profitability of their businesses. ${ }^{26}$ This is not to say that connections to political elites is irrelevant. As Burt and Opper note, 'China's business environment is designed to channel scarce resources and privileges to the country's ideologically favoured, politically wellconnected and oftentimes (partly) state-controlled corporations' ${ }^{27}$ However, successful Chinese enterprises in China have both political connections and advantaged business networks. ${ }^{28}$ Thus, we see a replica of this dual-model relationship in Africa, where the Chinese enterprises have connections both with the political elite and local patrons, of which the latter is key to the success of these Chinese enterprises.

In an empirically informed analysis of Chinese enterprises in Africa, Mohan and Lampert provide evidence to our assertion that local patrons play a deterministic role in Chinese business success. Mohan and Lampert note that 'Chinese entrepreneurs often

\footnotetext{
25 Gomez (2001)

${ }^{26}$ Meagher, Kate (2012), Weber meets Godzilla: social networks and the spirit of capitalism in East Asia and Africa, Review of African Political Economy, 39: 132

27 Burt, Ronald and Opper, Sonja (2020), Political Connection and Disconnection: Still a Success Factor for Chinese
}

emphasized that employing African labour was...essential to understanding the local market'. Thus, 'It was clear that their success depended on African actors in the form of their local workers' ${ }^{29}$

\subsection{How do Chinese construction companies operate in Ghana?}

From the late 1970s till about 2009/10, Chinese entrepreneurs were largely aided by the elites (and had exclusive privileges). Sometimes these elites were high government officials in or with connections to key ministerial posts who either went to China to strike deals with construction companies or aided the Chinese construction companies to set up in their respective countries and operate. The main motive was (1) to execute a government project that was crucial for the next elections at a lower cost or (2) for personal aggrandisement or even to promote their own local construction firms through a merger with the Chinese. During this era, the set up and operations of Chinese construction firms were largely in the hands of these elites.

However, from 2009/10 onwards, the relationship in that field (even the textiles field too) had come under severe criticisms from all angles: the West, African civil societies, opposition parties in African states etc. Also, there was a proliferation of Chinese construction companies in Ghana, as well as many parts of Africa, increasing the level of competition in the market. Thus, there was the need for the Chinese construction firms and African elites to create an alternative route for business. This is where local patrons 'emerged' (as in, not that they had not been there previously, but they became more prominent and increasingly essential to survive and succeed in the competitive construction sector). The local patrons became the channel through which the Chinese construction firms could access the state officials (elites) and their support and vice versa to remove the spotlight from the previously alleged corrupt interactions. It is important to also note that during the second era (2009/10 onwards) the proliferation of Chinese construction companies created a solid network for incoming Chinese entrepreneurs: the new ones could receive guidance/assistance from the old ones, or they could join resources to expand the business. At the same time, the incoming Chinese

Entrepreneurs, Entrepreneurship theory and practice, 44(6), p.1200

28 Ibid

${ }^{29}$ Mohan, Giles and Lampert, Ben (2013). Negotiating China: Reinserting African agency into China-Africa relations, African Affairs, 112(446), p.105 
construction firms spurred an increase in the demand for local patrons (for example, Mandarin translators who would act as a medium of communication between the Chinese, clients, and state officials).

These Chinese construction firms are profit-driven, so it often occurs that they would want quick procedures to set up the firm and start getting contracts. Thus, after official registration with the state has been done, the operation of the firm on the ground is where the local patrons become very crucial for the survival and profitability of the firm. Specifically, the embedded nature of African states has the propensity to develop very friendly and informal relations between businesses, locals, and the state - a tripartite relationship. ${ }^{30}$

\subsection{An indicative illustration from Chinese construction companies in Ghana}

This section draws on empirical evidence from field work conducted by the authors from November 2019 to July 2020. The companies and workers mentioned here are real but have been anonymised for obvious reasons. Though just a few examples are given, these examples reflect the general case in Ghana and many other African countries where Chinese construction companies operate. To begin, these Chinese construction firms were established in Ghana after 2010, mostly with some form of assistance from top state officials (elites) to get the necessary operating documents from the state. In some cases, these companies (especially the smaller ones) get their operating documents through the help of local patrons who can pay some monies to state agents to skip the cumbersome bureaucratic procedures. Hereafter, the ground operations of the firm is very dependent on local patrons: without them, the Chinese will not be able to navigate the market and communicate with clients. Meagher concurs to this and 'argues that when Chinese networks "touch ground" in Africa they become more like African networks, where forms of semi-legal brokerage by intermediaries enable these enterprises to operate'. ${ }^{31}$

Usually one finds these local patrons employed into managerial and technical positions within the company: some are General Managers (GM) with/without Chinese linguistic abilities, others are Mandarin translators who work both in the offices and on-site, others too are Africans who have lived/studied/worked in China but not necessarily

\footnotetext{
${ }^{30}$ Lam (2017)

31 Meagher (2012), quoted in Lampert and Mohan (2014), p.14; also in Lampert and Mohan (2015)
}

with Chinese linguistic skills, and there are those who are just in the technical team/ordinary workers but connected to the leadership at the local level (like chiefs, DCE, assembly men/women, MPs etc) by kin/family ties. Chinese entrepreneurs employ all these kinds of people into their firms because they recognise that the success/profitability of their firms (they know) depends on them.

In Company $X$ for instance, the Ghanaian manager is a well-connected person with links to the local state officials and excellent knowledge of the market (in terms of contracts and human resources). The Chinese therefore employed him for these advantages, and he helps them to get their imported goods from China cleared with ease and liaises with local state authorities on their behalf to get the Chinese out of trouble from, for example, tax evasion. Kernen and Lam also concur to this by noting that 'In general, Ghanaian management staff in Chinese companies often take up positions related to 'external affairs', such as accounting, sales, customs clearance, human resources that have to deal with authorities or local partners and employees.'32 Thus, 'The Ghanaian ones (referring to the managers) are responsible for dealing with the local authority'. ${ }^{33}$

In Company $\mathrm{Y}$ too, the HR manager (who is a Ghanaian hailing from the region of operation) had connections with the DCE (District Chief Executive), police (including the commanding officer), local fire service authorities, the local ECG (Electricity Company of Ghana), the local tax revenue authority and many other local authorities. This has built a very solid relationship between the Chinese and the local state authorities, which contributes to their operation in the community being both without strife and profitable. The Chinese owners of the company have built 'social capital' in making constant donations of all kinds to the local state authorities which puts them into their good books. This kind of relationship further opens the door to get contracts from the state, especially when they have been decentralised to the local state authorities: the Chinese become the 'best contractors' to execute the project for reasons of mutual benefits. That is, the local state authorities get to bargain at a favourable price with the Chinese contractors in a win-win fashion: the Chinese get the contract, the local state authorities get to profiteer from the contract.

In the last example, Company $Z$ has employed a 'local citizen' in addition to the other kinds of employees. This 'local citizen' has been a worker within the construction

32 Kernen, Antoine and Lam, Katy (2014), Workforce Localization among Chinese State-Owned Enterprises (SOEs) in Ghana. Journal of Contemporary China, 23(90), p.1067 ${ }^{33}$ Ibid 
sector for many years and as such knows all about the market and how to best secure contracts for private construction firms. The Chinese bosses therefore rely on him to scout the region or the market to bring in contracts for a handsome reward. Sometimes, even the Mandarin translators are also given an additional responsibility of scouting the market for individuals/firms that might want to undertake a construction project. The Chinese do this because there are so many of their colleagues now in the construction sector and this has made it very competitive and tight to come by contracts. Thus, the thriving companies are the ones that have employed this kind of 'local patron' to help them in their operations on the ground. Even Lampert and Mohan concurred to this in one of their previous works: 'local managerial and technical staff are also particularly helpful in understanding the local market, managing local workers, and negotiating the demands of local officials'. ${ }^{34}$ Again, they argue that 'many Chinese bosses have come to rely on senior local staff'. ${ }^{35}$

\section{ANALYSIS AND ASSESSMENT}

Though arguable, between the late 1990s till about 2010, African agency within the China-Africa relationship was mainly in the hands of African government officials at both the central and decentralised level. However, from 2010 to the present, African agency within the China-Africa relationship has significantly shifted into the hands of local citizens in African countries who are either employed in managerial/technical positions within Chinese firms or are people with linkages to the 'local patrons'. This shift can be attributed to the fact that in the early decades (even as far back as the 1970s when the TanZam railway was built), there were but few Chinese construction companies on the African continent, most of whom were there to execute Chinese aid projects. ${ }^{36}$ However, after China initiated the 'Go Out' (zou chuqu - 走出去) policy, many Chinese entrepreneurs ventured out into Africa, thus increasing their numbers and competition in the respective business sectors (in this case, the construction sector). Moreover, as is well known by now, the Africans were increasingly becoming wary of the Chinese, of whom they complained that they were taking their jobs. ${ }^{37}$ These events have thus compelled the Chinese to localise in the

\footnotetext{
34 Lampert and Mohan (2014), p.27

35 Ibid

36 Lam (2017)

37 Alden, Chris (2007), China in Africa (London; Zed Books).

38 Soulé-Kohndou, Folashadé, and Selormey, Edem E.

Selormey. (2020). How popular is China in Africa? New
}

African business environment by making friends not only with the elites, but more importantly the local patrons on whom the success of their business largely depends on.

Moreover, this shows that the long-held view that China-Africa relations 'are mostly organised via government to government relations' 38 is quite misleading as fieldwork in Africa reveals a quite different arrangement. Although China generally tends to approach African governments for the conduct of business and other economic policies, there is also the case where agents/individuals with a strong backing from the Chinese government approach African individuals (who may either be local patrons or people with links to the state) for the conduct of business. This gives the latter considerable powers that determine the success of Chinese firms on the African markets (for example, Mohan and Lampert cite examples of African individuals who partnered with Chinese companies to set-up a branch in Africa). ${ }^{39}$ Thus, this work also offers a revealing dimension of African agency at the most basic level that breaks away from the government-togovernment level analysis offered by Soule-Kohndou. ${ }^{40}$

Seen from the African perspective, the increased 'localisation' of the Chinese construction firms in the Ghanaian market can be explained by the fact that several local dynamics have made it conducive for the Chinese to operate in the country. First, more and more young students have mastered the Chinese language and become a reliable community of translators that can help bridge the language barrier between Chinese entrepreneurs and local Ghanaian clients. Secondly, the ability of Chinese construction firms to undertake infrastructural projects at a low cost and on time has also been noted by government officials who now rely heavily on Chinese construction companies to deliver on campaign promises (e.g., roads, bridges, hospitals, market complexes, schools) to citizens.

These reasons are also indicative of the case of other African countries (e.g., Ethiopia, Angola, and Kenya) where there is an increasing number of local citizens who are bilingual Chinese speakers. Also, several previous publications have shown that many African governments rely on Chinese construction firms to undertake infrastructural projects. ${ }^{41}$ In the future, more research can be conducted to examine if this holds across all the sub-regions of Africa or, if not, what are the

survey sheds light on what ordinary people think, The Conversation, 17 November 2020

${ }^{39}$ Mohan and Lampert (2015)

40 Soule-Kohndou (2020)

${ }^{41}$ See for example, Alves (2013); Alden (2007) 
differences between sub-Saharan Africa, North Africa and South Africa for example.

Finally, following from Abebe's work, we argue that this kind of relationship between the Chinese construction firms and the African elites and local patrons should not be seen as entirely negative. It is the modality of how businesses thrive in African settings, strengthening the state-society relations in many African countries. ${ }^{42}$ Seen from this perspective, Chinese businesses capacity to align their practices to this prevailing local logic enables the pursuit of profitability to become responsive to community concerns while contributing broadly and indirectly to national concerns as represented by state officials.

\section{CONCLUSION}

This relocation of agency, drawing from scholarship by Mohan, Lampert and Soule-Kohndou as well as the empirical materials based on substantive fieldwork, provides new insights into terms of engagement with local actors that form a bonded relationship facilitating integration of Chinese enterprises into the African political economy. By examining micro-level engagements between Africans and Chinese in Ghana, one can see that it is 'local patrons' in Africa whose actions are key determinants of the success of Chinese enterprises, serving as brokers between state officials and local communities, devising strategies to address and mitigate risk in new markets and ultimately ensuring the profitability of firms. To a greater extent than is found in macro and meso-level explanations, we believe that African agency resides in these individuals as linchpins between Chinese firms, the state apparatus and local communities.

\section{BIBLIOGRAPHY}

Abebe, Zekarias Beshah (2019), Developmental State and Ethnic Federalism in Ethiopia: Is Leadership the Missing Link? Journal of Leadership and Developing Societies, 3(1), pp. 95-127. https://doi.org/10.47697/lds.3436103

Alden, Chris, and Martyn Davies (2006), A profile of the operations of Chinese multinationals in Africa, South African Journal of International Affairs, 13:1, pp. 83-96.

Alden, Chris (2007), China in Africa (London: Zed Books).

42 Abebe, Zekarias Beshah (2019), Developmental State and Ethnic Federalism in Ethiopia: Is Leadership the Missing
Alves, Ana Cristina (2013), Chinese Economic Statecraft: A Comparative Study of China's Oil-backed Loans in Angola and Brazil, Journal of Current Chinese Affairs, 42:1, pp. 99-130

Anshan, L. (2018). African Students in China: Research, Reality, and Reflection. African Studies Quarterly, 17(4), 5-44.

Auffray, Cyrielle, and Xiaolan Fu (2015), Chinese MNEs and managerial knowledge transfer in Africa: the case of the construction sector in Ghana, Journal of Chinese Economic and Business Studies, 13(4), pp. 285-310. doi:10.1080/14765284.2015.1092415

Burt, Ronald and Opper, Sonja (2020), Political Connection and Disconnection: Still a Success Factor for Chinese Entrepreneurs, Entrepreneurship theory and practice, 44(6), pp. 1199-1228. doi:10.1177/1042258719893110

Chipaike, Ronald and Bishoff, Paul (2019) Chinese Engagement in Zimbabwe and the Limits of Elite Agency, Journal of Asian and African Studies 54:7, pp.947-964.

Corkin, Lucy (2013), Uncovering African Agency: Angola's Management of China's Credit Lines (Surrey: Ashgate)

Gelpern, A., Horn, S., Morris, S., Parks, B., and Trebesch, C. (2021), How China Lends: A Rare Look into 100 Debt Contracts with Foreign Governments (Peterson Institute for International Economics, Kiel Institute for the World Economy, Center for Global Development, and AidData at William \& Mary)

Gomez, Terence E. (2001), Chinese Business in Southeast Asia: contesting cultural explanations, researching entrepreneurship (Richmond: Curzon Press).

Hodzi, O. (2020), Bridging the asymmetries? African students' mobility to China, Asian Ethnicity, 21(4), 566-584.

doi:10.1080/14631369.2020.1776097

Kernen, Antoine and Lam, Katy (2014), Workforce Localization among Chinese State-Owned Enterprises (SOEs) in Ghana. Journal of Contemporary China, 23(90), pp. 1053-1072. doi:10.1080/10670564.2014.898894

Koning, Juliette (2007), Chineseness and Chinese Indonesian Business Practices: a Generational and Discursive Enquiry, East Asia, 24, pp. 129-152.

Kotkin, Joel (1993), Tribes: How Race, Religion and Identity Determine Success in the New Global Economy (New York: Random House).

Lam, Katy (2017), Chinese state-owned enterprises in West Africa: Tripleembedded globalization (Routledge).

Link? Journal of Leadership and Developing Societies, 3(1), pp. $95-127$ 
Lam, Katy, (2015), Chinese Adaptations: African Agency, Fragmented Community and Social Capital Creation in Ghana, Journal of Current Chinese Affairs, 44(1), pp. 9-41. doi:10.1177/186810261504400102

Lam, Katy and Bach, Jean-Nicholas (2014), L'INÉVITABLE «LOCALISATION»: LES ENTREPRISES PUBLIQUES CHINOISES DE LA CONSTRUCTION AU GHANA: China, Ltd. Un business africain, Politique africaine, 134, pp. 21-43.

Lampert, Ben and Mohan, Giles (2014), Sino-African Encounters in Ghana and Nigeria: From Conflict to Conviviality and Mutual Benefit, Journal of Current Chinese Affairs, 43(1), pp. 9-39 doi:10.1177/186810261404300102

Lampert, Ben and Mohan, Giles (2015), Making Space for African Agency in China-Africa Engagements: Ghanaian and Nigerian Patrons Shaping Chinese Enterprise, in A. W. Gadzala (Ed.), Africa and China: how Africans and their governments are shaping relations with China (Lanham, Maryland: Rowman \& Littlefield).

Mathews, Gordon (2015), African Logistics Agents and Middleman as Cultural Brokers in Guangzhou, Journal of Current Chinese Affairs, 4:4, pp.117-144

Meagher, Kate (2012), Weber meets Godzilla: social networks and the spirit of capitalism in East Asia and Africa, Review of African Political Economy, 39: 132, pp. 261-278

Mohan, Giles and Lampert, Ben (2013). Negotiating China: Reinserting African agency into China-Africa relations, African Affairs, 112(446), pp. 92-110. doi:10.1093/afraf/ads065

Procopio, Maddalena (2019), Kenyan agency in Kenya-China relations: Contestation, cooperation and passivity', In Alden, Chris and Daniel Large (eds.) (2019), New directions in Africa-China studies (LondresNova York: Routledge), pp. 173-188

Soulé-Kohndou, Folashadé, (2020), 'Africa+1' summit diplomacy and the 'new scramble' narrative: Recentering African agency, African Affairs, 119(477), pp. 633-646. doi:10.1093/afraf/adaa015

Soulé-Kohndou, Folashadé, and Selormey, Edem E. Selormey. (2020). How popular is China in Africa? New survey sheds light on what ordinary people think, The Conversation, 17 November 2020. Retrieved from https:/ / theconversation.com/how-popular-is-chinain-africa-new-survey-sheds-light-on-what-ordinary-people-think149552

Weidenbaum, Murray and Samuel Hughes (1996), The Bamboo Network: How Expatriate Chinese Entrepreneurs are Creating a New Economic Superpower in Asia (New York: Free Press). 